\title{
COMPARISON OF GRAZING IMPACTS BETWEEN THE INVASIVE NEW ZEALAND MUDSNAIL POTAMOPYRGUS ANTIPIDARUM, AND NATIVE MACROINVERTEBRATES
}

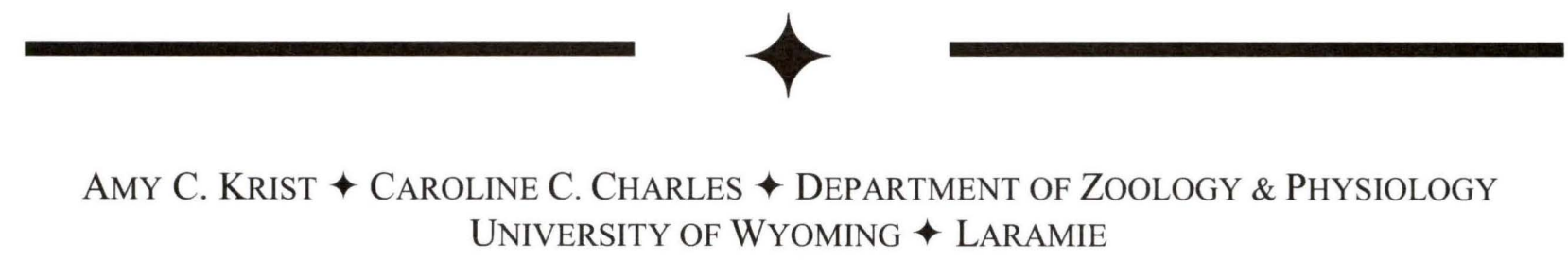

$\downarrow \quad$ Abstract

To understand the impacts of an herbivorous invasive species on native herbivores, it is critical to quantify the relative impact of the invasive and the native species on shared resources. In a field experiment, we compared grazing efficacy of periphyton by the invasive New Zealand mudsnail, Potamopyrgus antipodarum, and 3 native macroinvertebrate grazers. Depending on the measure of periphyton biomass, $P$. antipodarum removed as much or more periphyton than any of the native grazers. When we examined diatom genera individually, $P$. antipodarum also suppressed the relative abundance of the greatest number of diatom genera and suppressed those diatoms more than the native grazers. As a result, $P$. antipodarum should compete strongly for periphyton with native grazers. In particular, because Ephemerella mayflies were the second most effective grazers and grazed many diatom genera similarly to the invasive snails, these mayflies may be competing with $P$. antipodarum in the introduced range. Overall, grazing ability may contribute to the invasion success of $P$. antipodarum

\section{$\downarrow \quad$ INTRODUCTION}

Impacts of invasive species on native species have been documented at every level of ecological organization. Impacts range from effects on individuals, including behavioral modifications of native species in the presence of invasive species (Orrock and Danielson
2004) and hybridization (Perry et al. 2001), to ecosystem level effects, including domination of secondary production (Hall et al. 2006). and altered nutrient cycling (Gardner et al. 1995). Community level effects of invasive species include changes in community composition that can occur by extinction or altered interactions, including herbivory, predation and competition (Lockwood et al. 2007). Because organisms often compete for resources, one way to understand the impacts of invasive species on native species communities is to determine how invasive species use resources that are shared with native species and to compare the relative impact of invasive and native species on this shared resource. For consumers, knowledge of the extent of dietary overlap between native and invasive species is also required to determine which native species are likely competing with invasive species for resources.

We compared resource use between the invasive New Zealand mudsnail, Potamopyrgus antipodarum and 3 native macroinvertebrate species. This snail is a world-wide invader and was first observed in the western United States in 1987 (Bowler 1991). Subsequently, $P$. antipodarum have spread to freshwater habitats in most western states. In one stream in the Greater Yellowstone Area, $P$. antipodarum occur at densities exceeding 500,000 individuals $/ \mathrm{m} 2$ (Hall et al. 2006). This very high biomass coupled with high growth rates also dominates secondary production in streams in the Greater Yellowstone Area (Hall et al. 2006). Therefore, high growth rates of $P$. antipodarum and dominance in 
density and biomass may be caused by high assimilation efficiency or high foraging efficiency, allowing $P$. antipodarum to better utilize limited resources. Periphyton abundance is often limited in streams and consequently can limit populations of grazers (Feminella and Hawkins 1995). If $P$. antipodarum graze periphyton more effectively, this competitive advantage could lead to competitive dominance over native species that share limited resources.

Potamopyrgus antipodarum does compete with native grazers in the non-native range. In experimental conditions, P. antipodarum compete asymmetrically with 2 species of native snails (Riley et al. 2008, Krist and Dybdahl 2006). In both studies, exploitative competition for resources was the most likely mechanism for competitive interactions. Additionally, resource use by $P$. antipodarum suggests that these snails are likely competing with other native species: P. antipodarum consume $75 \%$ of gross primary productivity in one stream in the Greater Yellowstone Area (Hall et al. 2003).

In this experiment, we compared foraging efficiency between $P$. antipodarum and native grazers ( 2 caddisfly species and 1 mayfly species) on periphyton, their primary food resource along with detritus (Cope and Winterbourn 2004). We also compared the extent of dietary overlap in diatom consumption of $P$. antipodarum to the native grazers to identify the most likely competitors. Specifically, we asked whether periphyton abundance (ash free dry mass (AFDM) and chlorophyll $a$ ) differed among treatments grazed by $P$. antipodarum and native grazers. We also asked whether diatom assemblages differed between ungrazed tiles and tiles grazed by the invasive and native grazers.

\section{$\downarrow \quad$ MATERIAls AND Methods}

\section{Grazers}

For comparison to the New Zealand mudsnail, $P$. antipodarum, we examined the effect of grazing by 2 native caddisflies, Brachycentrus sp. and Glossosoma $s p$., and a native mayfly Ephemerella $s p$. We chose these native species because Brachycentridae and Ephemerellidae were negatively associated with densities of $P$. antipodarum in the Greater Yellowstone Area (Kerans et al. 2005). These insects may be negatively associated with $P$. antipodarum because of competitive interactions. We chose Glossosoma because a review of grazing experiments showed that members of this genus reduced periphyton levels more than any other caddisfly studied (Feminella and Hawkins 1995). Hence, all 3 of the native grazers that we studied are likely to be negatively affected by resource competition with $P$. antipodarum.

\section{$\uparrow \quad$ METHODS}

\section{Experiment}

To colonize periphyton for the grazing experiment, we set up grazer-excluding platforms holding unglazed tiles $\left(20 \mathrm{~cm}^{2}\right)$ in Polecat Creek (Roosevelt National Parkway, WY) in May 2007. The platforms, modeled after Lamberti and Feminella (1996), were all placed in a shallow riffle with similar, slow, flow regimes. We left the platforms in the stream for 20 days to allow periphyton to colonize and grow.

To obtain a sufficient biomass of grazers to significantly reduce periphyton, we used a biomass of $P$. antipodarum that had reduced algal biomass by $49 \%$ relative to ungrazed controls in an experiment by Winterbourn and Fegley (1989). We used this biomass because the ambient biomass of each grazer differed substantially. We adjusted the biomass of $P$. antipodarum used by Winterbourn and Fegley (1989) to the mean size of adult $P$. antipodarum that were available at our study site, and to the area of tiles and duration of grazing in our experiment. To control for biomass across different-sized species, we used the same biomass, $25.15 \mathrm{mg}$ ash free dry mass (AFDM) per cage, for all species. For each species, we used the mean size of 19-40 haphazardly chosen individuals to calculate the number required for each replicate. We used length - mass regressions (Benke et al. 1999) to convert mean length to AFDM. Regressions reported as dry mass were converted to AFDM using percent ash estimates provided by Benke and colleagues (1999). The number of individuals of each species required to obtain $25.15 \mathrm{mg}$ AFDM was 51 per replicate for $P$. antipodarum, 15 per replicate for Ephemerella, 115 per replicate Brachycentrus, and 16 per replicate for Glossosoma.

We placed a single tile colonized with periphyton and the animals into a cage and allowed them to graze for one week. The cages were made from square, plastic sandwich containers $\left(156.25 \mathrm{~cm}^{2}\right)$ with windows of $600-\mu \mathrm{m}$ mesh replacing the sides and tops. Two cages were attached to a brick with bolts and screws to maintain position in the stream. Twelve replicates of each grazer and 12 replicates of ungrazed controls (tile but no animals) were placed in the stream in areas of approximately equal flow rate. 
During the experiment, we removed debris and detached algae from the cages every other day. At the end of the experiment, we scrubbed the tiles with toothbrushes to remove the remaining algae and make a slurry. We divided the slurry that we collected from the tiles to quantify diatom assemblage $(1 \mathrm{ml})$, the amount of chlorophyll a $(2 \mathrm{ml})$, and AFDM (remaining slurry). Chlorophyll a was extracted using $90 \%$ buffered ethanol and quantified with a flourometer (Steinman et al. 2007). To measure AFDM we used vacuum filtration to place the remaining slurry onto preweighed ashed filters (Pall, A/E glass fiber filter). We dried the filters for 24 hours at $60^{\circ} \mathrm{C}$, weighed them, ashed them at $500^{\circ} \mathrm{C}$ for 1 hour and re-weighed the filters to obtain AFDM (Steinman et al. 2007).

To determine which diatoms were consumed in the periphyton, we preserved the slurry sample in $2 \%$ gluteraldehyde (Hill and Knight 1987) and then cleaned the diatoms with bleach. Cleaned diatoms were mounted on glass slides in naphrax, a mounting agent which facilitates identification by refracting light off of the diatom test. With these slides, we learned to identify diatoms to the genus level. We used this information to identify genera of diatoms in subsamples from each replicate. We counted diatoms (all intact diatoms and those that were at least $2 / 3$ complete) in a PalmerMaloney cell at $250 \mathrm{x}$ under a light, compound microscope. We counted until we reached 300 diatoms per replicate recording the number of fields of view required to calculate the total volume examined. We limited our analysis to diatoms because they were the most abundant constituents of the periphyton slurry in Polecat Creek.

\section{Statistical analysis}

We used planned comparisons between ungrazed controls and each of the grazing treatments to compare measures of chlorophyll a and AFDM among treatments. To adjust for multiple (3) comparisons, we used the Dunn-Sidak method to calculate an adjusted alpha of 0.0169 . We used principal components analysis, using the correlation matrix, to compare the diatom assemblages among treatments. We used oneway analysis of variance to compare PC1 and PC2 among treatments. All statistics were conducted using the R statistical package (R Development Core Team, 2008).

\section{$\uparrow \quad$ Results}

Because of mass mortality of Glossosoma, we omitted all replicates grazed by these caddisflies from the analyses. Similar levels of chlorophyll a and AFDM between the Glossosoma and control treatments indicates that the caddisflies grazed little before they died (Figs. 1,2). The number of replicates in the $P$. antipodarum and Ephemerella treatments was reduced from 12 to 11 because of cage failure and a presumed error in recording data that led to a negative concentration of chlorophyll $a$ (not a possible value).

Relative to the ungrazed controls, chlorophyll $a$ was only significantly reduced in the $P$. antipodarum $(\mathrm{t}=3.662$, d.f. $=13, \mathrm{p}=0.0027)$ and Ephemerella treatments $(\mathrm{t}=4.273$, d.f. $=12, \mathrm{p}=0.0011)$. Chlorophyll $a$ was not significantly reduced in the Brachycentrus treatment relative to the controls $(\mathrm{t}=-0.165$, d.f. $=21$, $\mathrm{p}$ $=0.8703$ ).

Relative to the ungrazed controls, AFDM was only significantly reduced in the $P$. antipodarum treatment $(\mathrm{t}=3.698, \mathrm{df}=13, \mathrm{p}=0.003)$. Ephemerella marginally reduced AFDM relative to the controls $(\mathrm{t}=2.436, \mathrm{df}=14, \mathrm{p}=0.028)$ while Brachycentrus did not reduce AFDM relative to the controls $(\mathrm{t}=1.1798$, d.f. $=$ $20, \mathrm{p}=0.252$ ).

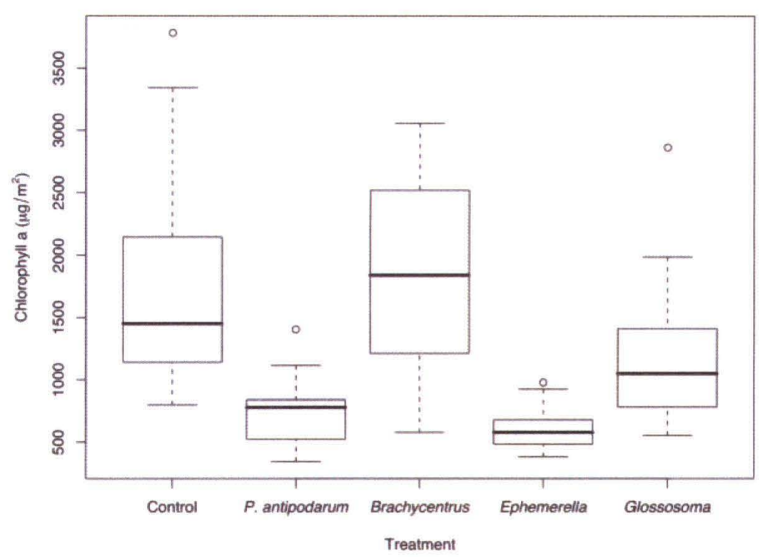

Fig 1. Chlorophyll $a$ of periphyton among experimental treatments. Relative to the ungrazed controls, chlorophyll $a$ was reduced in the tiles grazed by the invasive $P$. antipodarum $(\mathrm{t}=3.662$, d.f. $=13, \mathrm{p}=0.0027)$ and by Ephemerella mayfly nymphs $(\mathrm{t}=4.273$, d.f. $=12, \mathrm{p}=0.0011)$ but not by tiles grazed by Brachycentrus caddisfly larvae $(\mathrm{t}=$ -0.165 , d.f. $=21, p=0.8703)$. Note: because of mass mortality, Glossosoma caddisfly larvae were excluded from all analyses. 


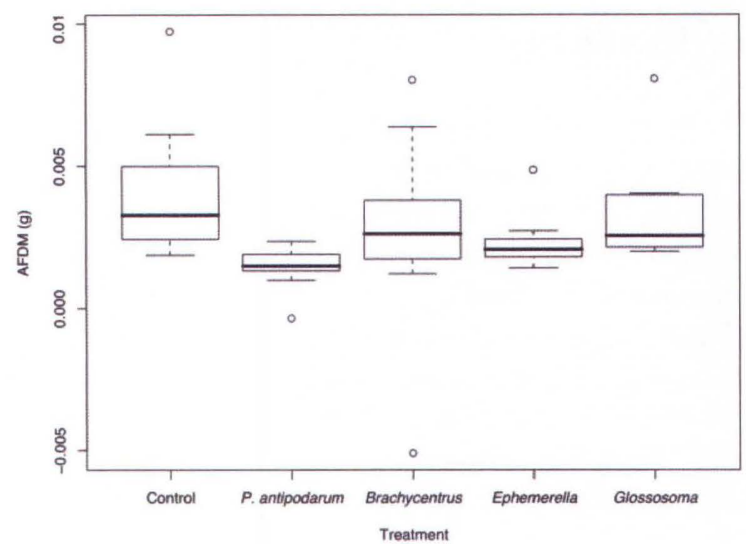

Fig. 2. Ash free dry mass (AFDM) of periphyton on experimental tiles $\left(20 \mathrm{~cm}^{2}\right)$. Relative to the ungrazed controls, AFDM was significantly reduced on the tiles grazed by the invasive $P$. antipodarum $(\mathrm{t}=3.698, \mathrm{df}=13, \mathrm{p}=0.003)$, marginally reduced on the tiles grazed by Ephemerella mayfly nymphs $(\mathrm{t}=2.436, \mathrm{df}=14, \mathrm{p}=0.028)$ and not reduced on tiles grazed by Brachycentrus caddisfly larvae $(\mathrm{t}=1.1798$, d.f. $=$ $20, \mathrm{p}=0.252$ ). Note: because of mass mortality, Glossosoma caddisfly larvae were excluded from all analyses.

Twenty different genera of diatoms were identified in slurries from tiles in the experiment. We lumped 4 diatom genera, Acnanthes, Mastoglia, Neidium, and Rhopalodia as rare diatoms because they represented less than $0.5 \%$ of the total diatoms. Compared to the ungrazed controls, the relative abundance (percent of total) of most diatoms was suppressed from grazing by 1 or more taxa (Figs. 3a, 3b). P. antipodarum suppressed the relative abundance either equal to or more than the other grazers for 10 of the 17 diatom genera (Figs. 3a, 3b). Ephemerella had the second largest impact on relative abundance of diatom genera (Figs. 3a, 3b). In contrast, compared to controls, the diatom Cocconeis increased in relative abundance in grazed treatments (Fig. 3a) and the diatoms Cymbella, Diatoma, Epithemia, Eunotia, Fragilaria, and the rare genera were very similar in relative abundance between grazed treatments and ungrazed controls (Figs. 3a, 3b).

We used principal components analysis to reduce the large number of diatom genera to a few key dependent variables that are composites of the original variables (Gotelli and Ellison, 2004). We analyzed principal components 1 and 2 ( $\mathrm{PC} 1, \mathrm{PC} 2)$ which comprised $40 \%$ of the variance in relative abundance of diatom genera. We were unable to interpret any additional principal components. ANOVA revealed differences among treatments in $\mathrm{PC} 1(\mathrm{~F}=3.14, \mathrm{df}=3$, $\mathrm{p}=0.03)$ and $\mathrm{PC} 2$ scores $(\mathrm{F}=5.75, \mathrm{df}=3, \mathrm{p}=0.002)$. For both PC1 and PC2, the greatest difference among treatments was between $P$. antipodarum and the ungrazed control treatments (Figs. 4, 5). Therefore, $P$. antipodarum altered the diatom assemblage more than any of the other grazers relative to the ungrazed controls.

PC1 explained $24 \%$ of the variance in relative abundance of diatom genera and differentiates between the diatom Cocconeis, and all other diatom genera (Table 1). Relative to ungrazed controls, Cocconeis increased in relative abundance in the treatments grazed by $P$. antipodarum and Ephemerella, whereas all other diatoms either decreased in relative abundance or were unaffected by grazing (Figs. 3a, 3b).

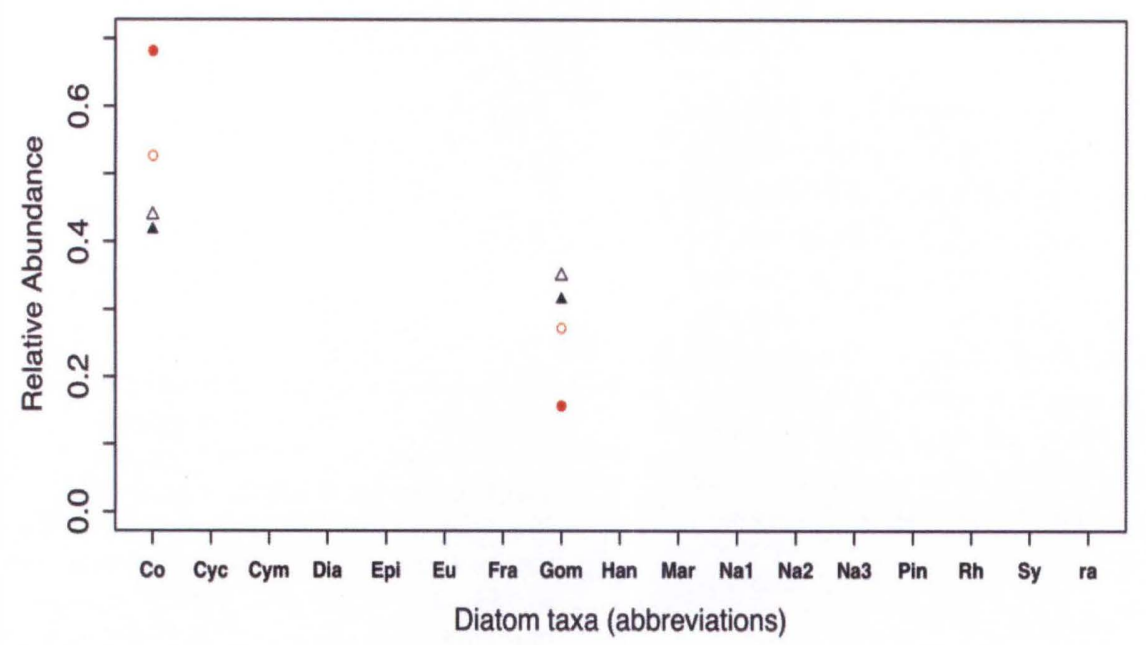




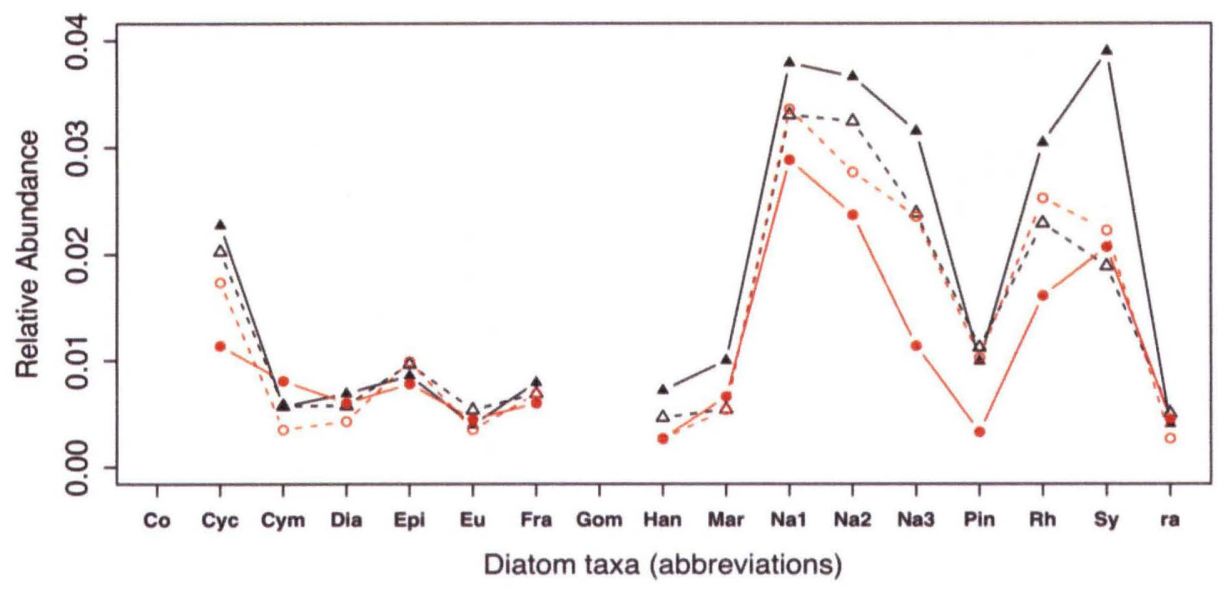

Fig. 3. Relative abundance of A) two most common diatom genera, Cocconeis (Co) and Gomphoneis (Gom) and

B) less common diatoms by experimental treatment $(\boldsymbol{\Lambda}$ with solid black lines $=$ ungrazed controls, $\Delta$ with black dotted lines $=$ Brachycentrus, $\boldsymbol{\bullet}$ with gray solid lines $=$ P. antipodarum, $\mathrm{O}$ with gray dotted lines $=$ Ephemerella ). Note the different scales on the y axes. Abbreviations for the other diatom genera are $\mathrm{Cyc}=$ Cyclotella, $\mathrm{Cym}=$ Cymbella, $\mathrm{Dia}=$ Diatoma, $\mathrm{Epi}=$ Epithemia, $\mathrm{Eu}=$ Eunotia, $\mathrm{Fra}=$ Fragilaria, Han $=$ Hantzschia, Mar $=$ Martyana, Nal, Na 2, Na 3 = Navicula types 1, 2,3, Pin = Pinnularia, $\mathrm{Rh}=$ Rhoicosphenia, Sy = Synedra and ra = rare ditaoms $($ Acnanthes, Mastoglia, Neidium, and Rhopalodia).

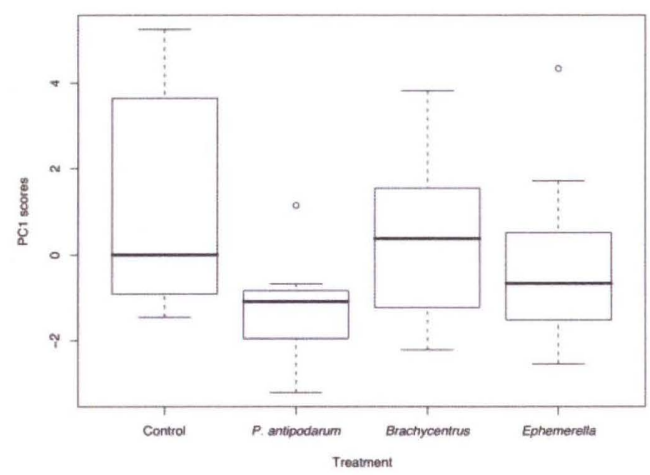

Fig. 4. $\mathrm{PCl}$ scores differ among experimental treatments (ANOVA: $\mathrm{F}=3.14, \mathrm{df}=3, \mathrm{p}=0.03$ ). Control tiles were not grazed. Tiles were grazed by, the invasive P. antipodarum, Brachycentrus, a larval caddisfly, or Ephemerella, a nymphal mayfly.

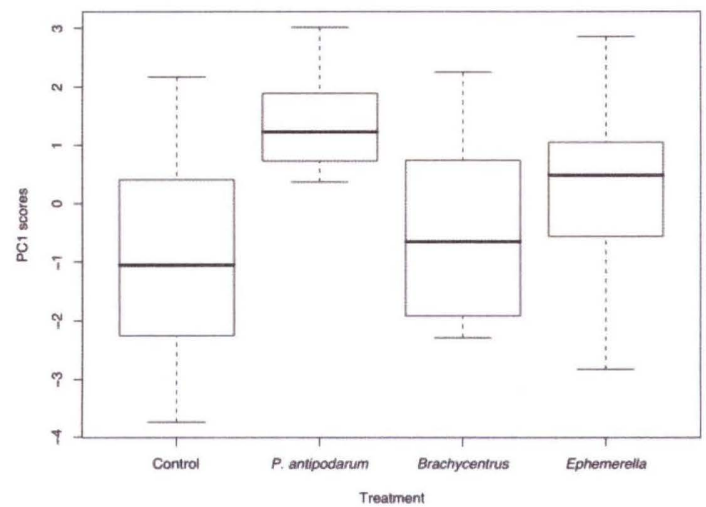

Fig. 5. PC2 scores differ among experimental treatments (ANOVA: $F=5.75, d f=3, p=0.002$ ). Control tiles were not grazed. Tiles were grazed by Potamopyrgus antipodarum, the invasive mudsnail, Brachycentrus, a larval caddisfly, or Ephemerella, a nymphal mayfly 
PC2 explained $16 \%$ of the variance in relative abundance of diatom genera and separates the control and Brachycentrus treatments from the Ephemerella and $P$. antipodarum treatments (Fig. 6). For the diatoms Gomphoneis, Cyclotella, Hantzschia, and Fragilaria (the diatoms with the largest negative loadings for PC2, Table 1), the control and Brachycentrus treatments are clustered (similar) and have higher relative abundances than the Ephemerella and P. antipodarum treatments, with P.antipodarum treatments possessing the lowest relative abundance for each of these diatoms (Figs. 3a, $3 b)$. In contrast, for the diatom genera Cocconeis and Rhoicosphenia (diatoms with the largest positive loadings for PC2, Table 1), the relative abundance of the treatment grazed by Ephemerella mayflies was equal to or higher than the treatment grazed by Brachycentrus, and closer in relative abundance to the Brachycentrus treatment than to the treatment grazed by the invasive snail P. antipodarum (Figs. 3a, 3b). Hence, PC2 separates diatom genera that are grazed similarly by $P$. antipodarum and Ephemerella from those that they graze differently.

\begin{tabular}{lll}
\hline Genus & PC1 & PC2 \\
\hline Epithemia & 0.184 & 0.177 \\
Cocconeis & -0.385 & 0.308 \\
Navicula 1 & 0.271 & -0.13 \\
Navicula 2 & 0.36 & -0.158 \\
Navicula 3 & 0.417 & 0.193 \\
Eunotia & 0.258 & \\
Synedra & 0.322 & \\
Rare & 0.198 & \\
Rhoicosphenia & 0.344 & 0.261 \\
Cyclotella & & -0.411 \\
Gomphoneis & & -0.467 \\
Diatoma & 0.171 &
\end{tabular}

$\begin{array}{lll}\text { Fragilaria } & & -0.379 \\ \text { Cymbella } & & 0.118 \\ \text { Martyana } & 0.127 & -0.119 \\ \text { Pinnularia } & 0.216 & \\ \text { Hantzschia } & & -0.394\end{array}$

Table 1. Principal component loadings for relative abundance of diatom genera. Rare includes Acnanthes, Mastoglia, Neidium, and Rhopalodia diatoms. Navicula 1, 2, and 3 were three distinctly different forms of the genus Navicula and likely represent different species. The blank values are loadings that are smaller than 0.1 .

\section{$\downarrow$ DISCUSSION}

Potamopyrgus antipodarum decreased AFDM of periphyton more than the other grazers and decreased chlorophyll a as much as the Ephemerella mayflies. Also, for the diatom genera that were reduced by grazing, $P$. antipodarum reduced the relative abundance of nearly all of these by more than any other grazing taxa. Therefore, the invasive $P$. antipodarum suppressed both total periphyton and most diatom genera more than any of the other grazers.

Studies in the native range of New Zealand have also shown $P$. antipodarum to be effective grazers. Winterbourn and Fegley (1989) found that $P$. antipodarum reduced algal biomass by $50 \%$ relative to ungrazed controls after 14 days. They also found that grazing by $P$. antipodarum altered the community of diatoms, leaving a structurally simpler community with much of the overstory removed (Winterbourn and Fegley 1989). Biggs and Lowe (1994) found that in field experiments in New Zealand, P. antipodarum were the most effective grazers and controlled periphyton abundance more than any other grazers. Also consistent with our study, Holomuzki and colleagues (2006) found that $P$. antipodarum were more effective at removing algal biomass than mayflies (Deleatidium spp.) and caddisflies (Pycnocentrodes aeris). However, in contrast to our study and to another study by one of the same authors using the same grazers, Holomuzki and Biggs (2006) found that $P$. antipodarum did not significantly reduce algal biomass and were less effective grazers than caddisflies $(P$. aeris) and mayflies (Deleatidium spp.). One possible 
explanation for such different results in two studies using the same grazers is that Holomuzki and Biggs (2006) did not control for biomass differences among grazers, so higher removal rates by caddiflies were attributed to larger body size combined with an abrasive case and higher activity levels. Overall, our study and other studies of $P$. antipodarum suggest that these snails are effective grazers and more effective than some caddisfly and mayfly grazers.

Relative to co-occurring grazers, are all freshwater snails effective grazers? The gastropod radula should facilitate grazing in snails because it permits access to diatoms with low profiles (Steinman, 1996). Indeed, other species of snails have been shown to be very effective grazers (Hawkins and Furnish 1987, Hill 1992). An alternative hypothesis for why $P$. antipodarum removed more diatoms than the other grazers could be physical abrasion caused by animal movements. However, this explanation seems unlikely as the movement of the soft gastropod foot seems less likely to remove periphyton than a caddisfly dragging its larval case made of stones (Glossosoma) or strands of vegetation (Brachycentrus).

In contrast to our study and to the findings of Holomuzki and colleagues (2006) on P. antipodarum, most studies show that caddisflies are often more effective grazers than most taxa of snails. For example, comparisons of grazing by snails (Juga) and larval caddisflies (Dicosmoecus) showed that the caddisfly was more effective at removing algal biomass (Steinman et al. 1987). Similarly, while both Juga snails and Dicosmoecus larval caddiflies significantly suppressed periphyton in a grazing experiment, the caddisfly larvae removed more periphyton than either the snails or Centroptilum mayfly nymphs (Lamberti et al. 1987). Neophylax caddisfly larvae also removed more periphyton than Ameletus mayfly nymphs (Hill and Knight 1987).

Caddisflies were not as effective at grazing in our experiment. One explanation is that although caddisflies in the genus Glossosoma have been shown to be very effective grazers (Feminella and Hawkins 1995), we were not able to compare grazing between these caddisflies and the other grazers because of unexplained mortality of Glossosoma in the experiment. The $600 \mu \mathrm{m}$ mesh walls of the cages may have reduced flow rates enough to lower oxygen levels to a level that was unsustainable for these caddisflies. Secondly, although Brachycentrus graze periphyton (Gallepp 1974), they are primarily collector-filterers (Wiggins 1996). Despite this, we included them in the experiment because members of the family
Brachycentridae were negatively correlated with $P$. antipodarum in several streams in the Greater Yellowstone Area (Kerans et al. 2005) suggesting possible competitive interactions. Also, Brachycentrus were effective grazers in a preliminary experiment, reducing both chlorophyll a and AFDM of periphyton relative to ungrazed controls (Krist 2007). This disparity in results between our current experiment and this preliminary experiment may be explained by seasonal changes in food availability for Brachycentrus. Perhaps Brachycentrus grazed in the preliminary experiment, conducted in July 2006, and not in the current experiment, conducted in June 2007, because levels of fine particulate organic matter (FPOM) were higher earlier in the summer. Relative to periphyton, FPOM is likely easier for these caddisflies to acquire with their long legs that are adapted to filter feeding (Wiggins 1996). Regardless of the explanation, we were not able to sufficiently address the grazing potential of either caddisfly in our experiment.

After P.antipodarum snails, Ephemerella mayfly nymphs were the second most efficient grazers. Similar to the invasive $P$. antipodarum, Ephemerella reduced or marginally reduced both measures of periphyton quantity, chlorophyll $a$ and AFDM, relative to ungrazed controls (Figs. 1, 2). In addition, mayflies grazed more similarly to the invasive $P$. antipodarum than the caddisflies. Of the 10 diatom genera that were grazed relative to controls (all but Cocconeis which increased in relative abundance and Cymbella, Diatoma, Epithemia, Eunotia, Fragilaria and rare diatoms which were minimally grazed), Ephemerella nymphs reduced the relative abundance of 9 diatom genera. Although Ephemerella usually have small effects on periphyton biomass (Kerans et al. 2005), these effects may appear larger in our experiment because of our inability to sufficiently address grazing by caddisflies. This is plausible because Brachycentrus grazed little and Glossosoma suffered high mortality and may not have had much opportunity to graze. It is also possible, however, that in our experiment, Ephemerella mayflies may have been effective grazers because the particular composition of diatom genera allowed them to effectively reduce periphyton abundance. The effect sizes in our experiment support this interpretation. Effect sizes are calculated as the magnitude of difference between the grazed and ungrazed controls (Feminella and Hawkins 1995). Effect sizes exceeding 1.5 have been suggested to indicate an ecologically significant grazing effect (Feminella and Hawkins 1995). For chlorophyll $a$, the effect sizes were 2.4 and 2.9 for P. antipodarum and Ephemerella mayflies respectively. For AFDM, the effect sizes were 2.7 and 1.74 for P. antipodarum and 
mayflies respectively. These effect sizes all exceed 1.5 and are comparable to effect sizes for taxa that had an intermediate effect on periphyton (Feminella and Hawkins 1995). Hence, in our experiment mayflies, along with $P$. antipodarum, were effective grazers.

Principal component 1 (PC1) revealed little information about relative grazing ability among the invasive and native macroinvertebrates. PC1 is explained by the increase in relative abundance of the solitary, small, diatom Cocconeis that lies adjacent to the substrate. Although all diatom genera decreased in density in all grazed treatments, Cocconeis increased in relative abundance because of a smaller decrease in density compared to the other diatom genera. Cocconeis increased in relative abundance more on tiles grazed by $P$. antipodarum than Ephemerella and Brachycentrus, most likely because $P$. antipodarum suppressed most other diatoms more than the other grazers. These results are not surprising because the small size and adnate (or adjacent to the substrate surface) posture of Cocconeis make these cells resistant to grazing (Kingston 2003). These results are consistent with a review of the effects of grazers on periphyton. Feminella and Hawkins (1995) found that most often, grazing caused a reduction of 1 or more numerically dominant diatom taxa with a corresponding increase in relative abundance of grazer-resistant taxa. Similarly, we found that grazing caused the reduction of the numerically dominant Gomphoneis in all grazed treatments except Brachycentrus, with reductions by $P$. antipodarum as high as $\sim 50 \%$ and an increase in the relative abundance of the grazer-resistant diatom Cocconeis (Fig. 3a). Gomphoneis were likely reduced by grazing because their cells grow from the point of attachment of long, mucilaginous stalks (Kociolek and Spaulding 2003) making them susceptible to grazing.

Besides Cocconeis, other diatom genera were also somewhat resistant to grazing. These were Cymbella, Diatoma, Epithemia, Eunotia, Fragilaria and the rare diatoms, Acnanthes, Mastoglia, Neidium, and Rhopalodia. The simplest explanation for why rare diatoms were not grazed is that they were so uncommon that they were not encountered by grazers. For the more common diatoms that were relatively ungrazed, physiognomy, the orientation and structure of diatom cells, affects susceptibility to grazing (Steinman, 1996). Two of the diatom genera, Epithemia and Eunotia, were likely protected from grazing by occurring singly (Table 2). Fragilaria and Diatoma grow in erect, stalkless, and thus short-statured, colonies that are less resistant to grazing but should still protect these cells from most grazers (Table 2). Although Cymbella form stalks, they are generally prostrate (Molloy 1992), which should confer some protection from grazers.

\begin{tabular}{|c|c|c|}
\hline $\begin{array}{l}\text { Characteristics of } \\
\text { diatoms }\end{array}$ & Physiognomy & References \\
\hline \multicolumn{3}{|l|}{$\begin{array}{l}\text { A) Grazing } \\
\text { resistant }\end{array}$} \\
\hline Cocconeis & $\begin{array}{l}\text { Occur singly, small } \\
\text { cells with adnate } \\
\text { posture }\end{array}$ & Kingston 2003 \\
\hline Cymbella & $\begin{array}{l}\text { Stalked, prostrate to } \\
\text { surface }\end{array}$ & Molloy 1992 \\
\hline Diatoma & $\begin{array}{l}\text { Erect, stalkless colonies } \\
\text { of short chains or } \\
\text { rosettes }\end{array}$ & $\begin{array}{l}\text { Wellnitz and } \\
\text { Ward 2000; } \\
\text { Molloy } 1992\end{array}$ \\
\hline Epithemia & $\begin{array}{l}\text { Occur singly, large } \\
\text { cells }\end{array}$ & Lowe 2003 \\
\hline Eunotia & Often occur singly & $\begin{array}{l}\text { Kociolek and } \\
\text { Spaulding } 2003\end{array}$ \\
\hline Fragilaria & $\begin{array}{l}\text { Erect stalkless colonies } \\
\text { shaped like ribbons, } \\
\text { bands, or rosettes }\end{array}$ & $\begin{array}{l}\text { Kingston 2003; } \\
\text { Molloy } 1992\end{array}$ \\
\hline \multicolumn{3}{|l|}{$\begin{array}{l}\text { B) Grazed most } \\
\text { effectively by P. } \\
\text { antipodarum and } \\
\text { then by } \\
\text { Ephemerella }\end{array}$} \\
\hline Cyclotella & $\begin{array}{l}\text { colonial, may form } \\
\text { linear chains or random } \\
\text { arrangements of cells in } \\
\text { the matrix }\end{array}$ & $\begin{array}{l}\text { Stoermer and } \\
\text { Julius } 2003\end{array}$ \\
\hline Gomphoneis & colonial, stalked & $\begin{array}{l}\text { Kociolek and } \\
\text { Spaulding } 2003\end{array}$ \\
\hline Hantzschia & $\begin{array}{l}\text { prostrate to the } \\
\text { substrate }\end{array}$ & Lowe 2003 \\
\hline Fragilaria & unstalked linear chains & Molloy 1992 \\
\hline \multicolumn{3}{|l|}{$\begin{array}{l}\text { C) Ephemerella } \\
\text { grazed more } \\
\text { similarly to } \\
\text { Brachycentrus }\end{array}$} \\
\hline Cocconeis & $\begin{array}{l}\text { adnate single, small, } \\
\text { cells }\end{array}$ & Kingston 2003 \\
\hline Rhoicosphenia & $\begin{array}{l}\text { adnate, growing in } \\
\text { branching tree-like } \\
\text { colonies }\end{array}$ & $\begin{array}{l}\text { Hudon and } \\
\text { Legendre 1987, } \\
\text { Molloy } 1992\end{array}$ \\
\hline
\end{tabular}

Table 2. Diatom genera are listed according to whether in this experiment they were A) relatively resistant to grazing, B) grazed most effectively by $P$. antipodarum and then by Ephemerella mayflies or C) Ephemerella grazed more similarly to Brachycentrus caddisflies. The diatom Cocconeis is listed twice because it falls into two of these categories. For each diatom genus, the physiognomy, or orientation and structure of diatom cells, and the references for that information are listed. Adnate refers to a posture that is adjacent to the surface of the substrate (in between prostrate and erect). 
PC2 separates diatom genera that were grazed most effectively by $P$. antipodarum and then by Ephemerella mayflies (Gomphoneis, Cyclotella, Hantzschia, and Fragilaria) from diatoms (Cocconeis, Rhoicosphenia) that Ephemerella grazed more similarly to Brachycentrus caddisflies. Differences in grazing efficacy of these diatom genera likely reflect differences in the ability of gastropod radulas and brush-like mouthparts of nymphal mayflies to remove diatoms as well as the physiognomy of the diatoms. The genera grazed more similarly by $P$. antipodarum and Ephemerella include 2 colonial genera, Gomphoneis and Fragilaria, whose upright postures make them susceptible to grazing (Table 2). In contrast, the physiognomy of Cyclotella and Hantzschia should confer more resistance to grazers; Cyclotella because the colonial cells occur in the matrix (Stoermer and Julius 2003) and Hantzschia because the cells are prostrate to the substrate (Table 2). Despite this variety of diatom growth forms, $P$. antipodarum grazed these genera most effectively and mayflies grazed them second most effectively. Physiognomy may also explain why 2 of the diatom genera were grazed most similarly by mayflies and caddisflies. These genera, Cocconeis and Rhoicosphenia, appear to be similar in their susceptibility to grazing. Both diatoms are adnate, a posture which should protect them from most grazers (Table 2). In our experiment Cocconeis resisted grazing by all taxa (Fig. 3a) while Rhoicosphenia was most susceptible to grazing by $P$. antipodarum and was grazed similarly and not as effectively by Ephemerella and Brachycentrus (Fig. 3b). Therefore, in our experiment mayfies and caddisflies were similarly disadvantaged grazing these adnate diatoms.

Taken together these results provide several insights regarding interactions between grazers and periphyton and between invasive $P$. antipodarum and native grazers. First, these results suggest that $P$. antipodarum are more effective grazers than Ephemerella mayflies and Brachycentrus caddisflies because they significantly reduced both measures of periphyton biomass (chlorophyll $a$ and AFDM) and they reduced the relative abundance of more diatom genera than any of the native grazers. This superior grazing ability suggests that $P$. antipodarum should be strong competitors for periphyton with native grazers. Second, these results suggest that compared to Brachycentrus caddisfly larvae, Ephemerella mayfly nymphs are the second most effective grazers at removing both total periphyton biomass and individual diatom genera. Because the Glossosoma caddisfly larvae died during the experiment, an adequate comparison of their grazing ability could not be made. The similarity in grazing ability and diatom genera grazed between $P$. antipodarum and Ephemerella mayflies suggests that in this experiment Ephemerella have the greatest dietary overlap with $P$. antipodarum and are the most likely to be competing with these invaders. Third, these results suggest that higher grazing efficacy relative to native grazers may be a potential mechanism for $P$. antipodarum dominance in biomass (Hall et al. 2006) which should protect them from most grazers (Table 2). In our experiment Cocconeis resisted grazing by all taxa (Fig. 3a) while Rhoicosphenia was most susceptible to grazing by $P$. antipodarum and was grazed similarly and not as effectively by Ephemerella and Brachycentrus (Fig. $3 \mathrm{~b})$. Therefore, in our and experiment mayflies and caddisflies were similarly disadvantaged grazing these adnate diatoms. and consumption of primary productivity (Hall et al. 2003). More experiments are needed to compare grazing ability between the invasive $P$. antipodarum and other native macroinvertebrate grazers. These results suggest, however, that grazing ability may contribute to invasive success in $P$. antipodarum.

\section{$\downarrow$ ACKNOWLEGEMENTS}

We gratefully acknowledge funding from the National Park Service (A. Krist) and National Science Foundation EPSCoR fellowships to C. Charles to support this work. We also thank Hank Harlow and the staff at the University of Wyoming- National Park Service Research Station at the AMK ranch for research space and lodging. Thanks also to Teresa Tibbets who assisted in the field and Joe Bobbitt and Steve DeVries who constructed the cages and the grazer-excluding platforms. This manuscript was improved by discussions with Erin Hotchkiss, Heather Julien, Lisa Kunza, Charlotte Narr, and Leslie Riley.

\section{$\downarrow$ Literature Cited}

Benke, A.C., A.D. Huryn, L.A. Smock and J.B. Wallace. 1999. Length-mass relationships for freshwater macroinvertebrates in North America with particular reference to the southeastern United States. Journal of the North American Benthological Society 18:308-343.

Biggs, B.J.F. and R.L Lowe. 1994. Responses of two trophic levels to patch enrichment along a New Zealand stream continuum. New Zealand Journal of Marine and Freshwater Research 28:119-134. 
Bowler, P.A. 1991. The rapid spread of the freshwater hydrobiid snail Potamopyrgus antipodarum (Gray) in the Middle Snake River, southern Idaho. Pages 173-182 In: Proceedings of the Desert Fishes Council, E.P. Pfister (ed.). Volume XXI (Twenty First Annual Symposium). Omnipress, Madison, Wisconsin.

Cope, N.J. and M.J. Winterbourn. 2004. Competitive interactions between two successful molluscan invaders of freshwaters: an experimental study. Aquatic Ecology 38:83-91.

Feminella, J.W. and C.P. Hawkins. 1995. Interactions between stream herbivores and periphyton: a quantitative analysis of past experiments. Journal of the North American Benthological Society 14:465-509.

Gallepp, F. 1974. Diel periodicity in the behavior of the caddisfly Brachycentrus americanus (Banks). Freshwater Biology 4:193-204.

Gardner, W.S., J.F. Cavaletto, T.H. Johengen, J.R. Johnson, R.T. Heath and J.B. Cotner. 1995. Effects of zebra mussel, Dreissana polymorpha, on community nitrogen dynamics in Saginaw Bay, Lake Huron. Journal of Great Lake Research 21:529-544.

Gotelli, N. J. and A. M. Ellison. 2004. A primer of Ecological Statistics. Sinauer Associates, Sunderland, Massachusetts.

Hall, R.O. Jr., M.F. Dybdahl and M.C. Vanderloop. 2006. Extremely high secondary production of introduced snails in rivers. Ecological Applications 16:1121-1131.

Hall, R.O. Jr., J.L. Tank and M.F. Dybdahl. 2003. Exotic snails dominate nitrogen and carbon cycling in a highly productive stream. Frontiers in Ecology and the Environment 1:407-411.

Hawkins, C.P. and J.K. Furnish. 1987. Are snails important competitors in stream ecosystems? Oikos 49:209-220.

Hill, W.R. 1992. Food limitation and interspecific competition in snail-dominated streams. Canadian Journal of Fisheries and Aquatic Sciences 49:1257-1267.
Hill, W.R. and A.W. Knight. 1987. Experimental analysis of the grazing interaction between a mayfly and stream algae. Ecology 68:19551965.

Holomuzki, J.R. and B.J.F. Biggs. 2006. Food limitation affects algivory and grazer performance for New Zealand stream macroinvertebrates. Hydrobiologia 561:83-94.

Holomuzki, J.R., R.L. Lowe and J.A. Ress. 2006. Comparing herbivory effects of stream macroinvertebrates on microalgal patch structure and recovery. New Zealand Journal of Marine and Freshwater Research 40:357367.

Hudon, C. and P. Legendre. 1987. The ecological implications of growth forms in epibenthic diatoms. Journal of Phycology 23:434-441.

Kerans, B.L., M.F. Dybdahl, M.M. Gangloff, and J.E. Jannot. 2005. Potamopyrgus antipodarum: distribution, density, and effects on native macroinvertebrate assemblages in the Greater Yellowstone Ecosystem. Journal of the North American Benthological Society 24:123-138.

Kingston, J.C. 2003. Araphid and monoraphid diatoms. Pages 595-636 In: Freshwater Algae of North America: Ecology and Classification. J.D. Wehr and R.G. Sheath (eds). Academic Press, San Diego, California.

Kociolek, J.P. and S.A. Spaulding. 2003. Eunotoid and assymetrical Naviculoid diatoms. Pages 655668 in J. D. Wehr and R. G. Sheath (eds). Freshwater Algae of North America: Ecology and Classification. Academic Press, San Diego, California.

Krist, A.C. and M.F. Dybdahl. 2006. The invasive New Zealand mudsnail, Potamopyrgus antipodarum, reduces growth of the native snail, Fossaria sp. University of Wyoming, National Park Service Research Center, 29th Annual Report: 42-48.

Krist, A.C. 2007. Grazing effects of the invasive mudsnail, Potamopyrgus antipodarum and two native invertebrates. University of Wyoming, National Park Service Research Center, 29th Annual Report: 105-109. 
Lamberti, G.A., L.R. Ashkenas, S.V. Gregory, A.D. Steinman. 1987. Effects of three herbivores on periphyton communities in laboratory streams. Journal of the North American Benthological Society 6:92-104.

Lamberti, G.A. and J.W. Feminella. 1996. PlantHerbivore Interactions. Pages 409-430 In: Methods in Stream Ecology. F.R. Hauer, G.A. Lamberti (eds). Academic Press, San Diego, California.

Lockwood, J.L., M.F. Hoopes and M.P. Marchetti. 2007. Invasion Ecology. Blackwell Publishing, Malden, Massachusetts.

Molloy, J.M. 1992. Diatom communities along stream longitudinal gradients. Freshwater Biology 28:59-69.

Orrock, J.L. and B.J. Danielson. 2004. Rodents balancing a variety of risks: invasive fire ants and indirect and direct indicators of predation risk. Oecologia 140:662-667.

Perry, W.L., J.L. Feder and D.M. Lodge. 2001. Implications of hybridization between introduced and resident Orconectes crayfishes. Conservation Biology 15:1656-1666.

R Development Core Team. 2008. R: A language and environment for statistical computing. $\mathrm{R}$ Foundation for Statistical Computing, Vienna, Austria. ISBN 3-900051-07-0, URL http://www.R-project.org

Riley L.A., M.F. Dybdahl and R.O. Hall Jr. 2008. Invasive species impact: asymmetric interactions between invasive and endemic freshwater snails. Journal of the North American Benthological Society 27:509-520.

Steinman, A.D. 1996. Effects of grazers on freshwater benthic algae. Pages 341-373 In: Algal Ecology: Freshwater Benthic Ecosystems. R.J. Stephenson, M.L. Bothwell and R.L. Lowe (eds). Academic Press, San Diego, California.
Steinman, A.D., G.A. Lamberti, P.R. Leavitt. 2007. Biomass and pigments of benthic algae. Pages 357-379 In: Methods in Stream Ecology. 2nd edition. F.R. Hauer and G.A. Lamberti (eds). Academic Press, San Diego, California.

Steinman, A.D., C.D. McIntire, S.V Gregory, G.A. Lamberti, and L.R. Ashkenas. 1987. Effects of herbivore type and density of taxonomic structure and physiognomy of algal assemblages in laboratory streams. Journal of the North American Benthological Society 6:175-188.

Stoermer, E.F. and M.L. Julius. 2003. Centric diatoms. Pages 559-594 In: J.D. Wehr and R.G. Sheath (eds). Freshwater Algae of North America: Ecology and Classification. Academic Press, San Diego, California.

Wellnitz, T.A. and J.V.Ward. 2000. Herbivory and irradiance shape periphytic architecture in a Swiss alpine stream. Limnology and Oceangraphy 45:64-75.

Wiggins, G.B. 1996. Trichoptera Families. Pages 309349 In: An Introduction to the aquatic insects of North America. R.W. Merritt and K.W. Cummins (eds.) Kendall/Hunt Publishing, Dubuque, Iowa.

Winterbourn, M.J. and A. Fegley. 1989. Effects of nutrient enrichment and grazing on periphyton assemblages in some spring-fed, south island streams. New Zealand Natural Sciences 16: $57-65$. 